Trakya Eğitim Dergisi

Cilt 10, Sayı 1

Ocak 2020, 112-126

Geliș Tarihi: 07.04.2019.

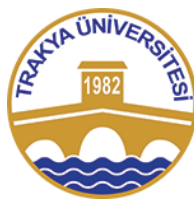

ISSN: $2630-6301$

Doi: $10.24315 /$ tred. 550508

Araştırma Makalesi/

Research Article
Trakya Journal of Education

Volume 10, Issue 1

January 2020, 112-126

Yayına Kabul Tarihi: 12.02.2020.

\title{
2018 Sosyal Bilgiler Dersi Öğretim Programının Değerlendirilmesi ${ }^{1}$
}

\section{Evaluation of the 2018 Social Studies Curriculum}

\section{Cemil ÖZTÜRK ${ }^{2}$, Tuğba KAFADAR ${ }^{3}$}

\begin{abstract}
ÖZ: Araştırmada 2018 yılında yürürlüğe giren sosyal bilgiler dersi öğretim programı değerlendirilmesi amaçlanmıştır. Araştırmada veriler doküman incelemesi ile toplanmıştır. Ulaşılan veriler içerik analizi yöntemine tabi tutulmuştur. Araştırmanın sonuçlarına göre; sosyal bilgiler dersi öğretim programı dersin kendisine ait ayrı bir perspektif ve amaçlara sahip değildir. İçerik kısmında, değer ve beceri eğitimi programda ayrı bir ders veya konu alanı olarak değil tüm derslerle bütünleşik olarak verilmektedir. Programın öğrenme öğretme sürecinde ise; harmonik, çokdisiplinli, genelden özele, somuttan soyuta, basitten karmaşığa, bütünsel, öğrenci merkezli, öğrenme alanlarına dayalı, değer ve yetkinlikler temelli, bilgi, beceri ve davranış kazandırmayı hedefli bir yaklaşım benimsendiği ifade edilebilir. Ancak programda hangi ölçme değerlendirme yöntem ve tekniklerinin kullanılacağına dair açıklamalar bulunmamaktadır.
\end{abstract}

Anahtar sözcükler: Sosyal bilgiler, öğretim programı, değerlendirme, içerik analizi

\section{Cite this article as:}

Öztürk, C. \& Kafadar, T. (2020). Evaluation of the 2018 social studies curriculum. Trakya Eğitim Dergisi, 10(1), 112-126.

\section{EXTENDED ABSTRACT}

\section{Introduction}

Together with globalization, there have been changes in the world in many fields such as scientific, technological, social and cultural. Societies have had to keep up with these changes and felt the need for renewal constantly on many areas according to the conditions of the period. Education, which is one of these fields. Turkey social studies curriculum was renewed in 2018. Evaluation of the social studies curriculum renewed in 2018 is important in terms of discovering the deficiencies of the program. Furthermore, it can contribute to the field in terms of making comparison with the curriculums published in recent years in other countries and observing the current situation of the curriculum. In the research, evaluation of the social studies curriculum that came into force in 2018 was targeted.

\section{Method}

The research was designed according to the case study which is one of the qualitative research designs. In the research, the social studies curriculum that came into force in 2018 was accepted as a case and evaluated. The study group of the research was determined according to the purposive sampling method. In the research, the new social studies curriculum that came into force in 2008 was handled as the study group. In the research, the data was collected through document analysis. The research data was analyzed with the content analysis method. In this phase, the data were analyzed and were coded. The obtained codes were gathered and analyzed and classified according to their common

\footnotetext{
${ }^{1}$ Bu çalışmanın bir kısmı 7. Uluslararası Sosyal Bilgiler Eğitimi Sempozyumunda sözlü bildiri olarak sunulmuştur.

${ }^{2}$ Prof. Dr., Marmara Üniversitesi, Atatürk Eğitim Fakültesi, Türkçe ve Sosyal Bilimler Eğitimi Bölümü, cozturk@marmara.edu.tr, ORCID ID: 0000-0002-2433-350X

${ }^{3}$ Dr. Öğr. Üyesi, Erciyes Üniversitesi, Eğitim Fakültesi, Türkçe ve Sosyal Bilimler Eğitimi Bölümü, tugbakafadar@gmail.com, ORCID ID: 0000-0002-4573-9250
} 
grounds. In this way, thematic coding was done. The obtained codes were organized under appropriate themes. The codes were tabulated by gathering under categories, definitions and interpretations were made. In order to support the obtained data, sample quotations were chosen from the documents and findings were explained with the support of the quotations.

\section{Results and Discussion}

When the Turkey social studies curriculum published in 2018 is evaluated with an integrated approach, the results are as follows: Social studies curriculum was evaluated in four dimensions in general. When the curriculum is analyzed, the objectives dimension consists of perspective, objectives and specific objectives. The social studies curriculum does not have a separate perspective belonging to the course. The perspective of the curriculum is given generally for all courses. In the perspective of the curriculum, it is aimed to develop skill and behavior based on values and competences. In the social studies curriculum, the learning domains, which are the "individual and society, people, places and environments, global connections, production, distribution and consumption, active citizenship, science, culture and heritage, technology and society" are included. The gains in the curriculum are included within the framework of the learning domains and proceed in parallel with each other generally on all class levels and learning domains quantitatively. Value and skill education are provided as a separate course in the curriculum and given as integrated with all courses rather than a subject area. In the curriculum, the values and skills to be gained were also listed. In the learning and teaching process of the social studies curriculum, it can be stated that a harmonic, multidisciplinary, from general to specific, from concrete to abstract, simple to complex, holistic, student-centered, learning domainbased, value and competence-based approach aiming at gaining knowledge, skill and behavior was adopted. The evaluation dimension proceeds with a diversity and flexibility understanding based on the principle that every individual is different from each other. In the curriculum, a multi-focused and process-oriented evaluation approach was adopted.

As a result of the evaluation of the social studies curriculum coming into force in 2018; the most general objectives of the curriculum are expressed with the perspective. When the vision of the social studies curriculum which came into force in 2005 is analyzed, developing knowledge, skill, value and behavior is targeted. When the social studies curriculums of different countries are analyzed, it is observed that developing knowledge, skill, value and behavior is targeted in NCSS (1994) and USA (New York) (2016) curriculums. These results contain similar objectives with the social studies curriculum published in Turkey in 2018. The objectives are more detailed in the previous Turkey social studies curriculum and the specific objectives of the curriculum are almost the same with the general objectives of the 2005 social studies curriculum. In the social studies curriculum published in 2018, active citizenship learning domain is included differently from the previous curriculum. Value and skill education are provided as a separate course in the curriculum and given as integrated with all courses rather than a subject area. The Partnership for 21st Century Learning (P21), founded in the USA in 2002, puts forward that students need to gain the skills which are building blocks for the 21 st century citizenship education. These skills are as follows: "1) communication, 2) critical thinking and problem solving, 3) creativity and innovation 4) collaboration skills" (P21, 2016). When the Turkey social studies curriculum is analyzed comparatively with the international literature, it is seen that there are more detailed skills. In the social studies curriculum published in 2018, it is stated that the curriculum is interdisciplinary. However, it can be stated that it is not interdisciplinary but it is multidisciplinary. Interdisciplinary approach was adopted in the previous curriculum. NCSS explains that social studies curriculum needs to be interdisciplinary. However, it can be stated that the curriculums of the countries like the USA (New York) and France published and revised in the recent years are also multidisciplinary. In the curriculum, the basic principles as measurement and evaluation are specified but there are no explanations on which measurement and evaluation methods and techniques will be used.

\section{GİRIS}

Küreselleşmeyle dünyada bilimsel, teknolojik, sosyal ve kültürel olmak üzere birçok alanda değişimler meydana gelmiştir. Değişim yaşanan alanlardan birisi de eğitimdir. Eğitim alanında 
toplumlar herhangi bir ülkenin ihtiyaçlarına göre zamanın şartlarına uygun olarak değişimler yaşayabilmektedir. Bireylerin toplum içinde etkin vatandaşlar olarak yer alabilmeleri için gerekli bir ders olan sosyal bilgiler eğitiminde de zaman zaman değişim ve yenilenmeler yaşanabilmektedir. Türkiye sosyal bilgiler dersi öğretim programıda 2018 y1lında yenilenmiştir. Bireylerin toplumsal yaşamda aktif, katılımcı olmasını gerektiren ve sivil yeterliliklerinin geliştirilmesini hedef edinen sosyal bilgiler NCSS (2010), bir konu alanı olarak ilk defa ABD'de ortaya çıkmıştır. ABD'de bireyler karşılaştıkları sorunlara çözüm bulmak için çareyi eğitimde görmüşler ve ülkenin yaşadığı sorunlara çözüm bulmak amaciyla sosyal bilgiler doğmuştur (Evans, 2011). 1916'da Ulusal Ĕgitim Birliği'nin (NEA) ortaokullarda sosyal bilgiler raporunu yayınlamasıyla (Evans, 2004) yaygınlık kazanmıştır.

Sosyal bilgiler Sosyal Bilgiler Ulusal Konseyi ne göre, sosyal ve beșeri bilimlerin vatandaşlik özelliklerini kazandırmak amaçlı bütünsel çalışmasıdır (NCSS, 2010). Ayrıca sosyal bilgiler, günümüzde karar verebilen, problem çözebilen etkin vatandaşlar yetiştirmek amaç edinen öğretim programıdır (Öztürk, 2009). Sosyal bilgiler, bireylerin bilişsel, duyuşsal ve devinimsel olarak gelişmesi sürecine katkıda bulunmaktadır. Bu boyutlarda sosyal bilgilerin amaçlarının temelini olușturmaktadır (Doğanay, 2009). ABD, Avustralya ve Kanada gibi birçok ülkenin sosyal bilgiler dersi öğretim programının iki genel amacı bulunmaktadır. Bunlar, dünyayı anlama ve vatandaşlık sorumluluğu olarak toplumsal yaşama katılımdır. Bu iki genel amaç birbirine bağlıdır. Çünkü dünyayı anlamayan bir kişi etkin vatandaş olarak topluma katkıda bulunamaz (Barr, 1997). Sosyal bilgiler, değișen toplumların ürünüdür. Güçlü bir sosyal bilgiler öğretiminin amacı öğrencilerin bilgi, beceri ve katılımcı vatandaş özelliklerini kazandırmaktır. Okullar katkıda bulunan vatandaşlar yetiştirerek topluma yardımcı olmak, öğrencilerin kendi potansiyellerine ulaşmalarını sağlayarak mutlu yaşam sürmelerine katkıda bulunmak amacindadir. Sosyal bilgilerin konusu budur (Turner, Russell III ve Waters, 2013). Sosyal bilgiler dersi öğretim programı, sınıfta kişisel ve duygusal okuryazarlığın sosyal gelişimine etkide büyük rol oynamaktadır (Mindes, 2014).

Sosyal bilgilerin birçok ülkede (Amerika Birleşik Devletleri, Finlandiya, Türkiye, Yeni Zelanda gibi) eğitimi verilmektedir. $\mathrm{Bu}$ dersin eğitim ve öğretimi sürecinde öğretim programı kullanılabilmektedir. Öğretim programları Erden'e (2015) göre, her ders için ayrı olarak hazırlanarak, eğitim ve öğretim sürecinde öğretmene rehber görevi yapmaktadır. Öğretim programları genellikle "hedef, kapsam, eğitim durumları ve değerlendirmeden" oluşur. 2018 yılında yenilenen sosyal bilgiler dersi öğretim programının değerlendirilmesi programın eksikliklerini görme açısından önemli görülebilir. Ayrıca diğer ülkelerde son yıllarda yayınlanan öğretim programları ile karşılaştırma ve programların mevcut durumunu görme imkânı vermesi açısından alana katkı sağlayabilir.

İlgili literatür incelendiğinde sosyal bilgiler dersi öğretim programıla ilgili birçok çalışma bulunmaktadır. Bu çalışmalar; sosyal bilgiler dersi öğretim programının değerlendirilmesi (Doğanay, 2008; Ersoy, 2009; Arslan ve Demirel, 2007); sosyal bilgiler dersi öğretim programına yönelik öğretmenlerin görüşleri (Yapıcı ve Demirdelen, 2007; Ayten, 2006; Doğanay ve Sarı, 2008); sosyal bilgiler dersi programı uygulanma düzeyinin değerlendirilmesi (Gömleksiz ve Bulut, 2006); öğrenci görüşlerine göre sosyal bilgiler dersi programının değerlendirilmesi (Akdağ, 2009); sosyal bilgiler dersi programının uygulanma düzeyine ilişkin öğrencilerin görüşlerinin değerlendirilme yapılması (Ersoy ve Kaya, 2009); alan uzmanlarının görüşlerine göre 2017 sosyal bilgiler dersi programının incelenmesi (Koçoğlu ve Aydın, 2017); sosyal bilgiler dersi programı ölçme değerlendirme öğelerine ilişkin öğretmen görüsşleri (Kabapınar ve Ataman, 2010; Algan, 2008); 2005 ile 2017 sosyal bilgiler dersi programlarının karşılaştırılmalı olarak incelenmesi (Çoban ve Akşit, 2018); sosyal bilgiler dersi öğretim programında değerler eğitimi (Keskin, 2008; Yalar, 2010); sosyal bilgiler dersi öğretim programındaki değerlere yönelik öğretmen görüşleri (Balcı ve Yelken, 2013); sosyal bilgiler dersi öğretim programının ulusal ve evrensel değerler yönünden incelenmesi (Evin ve Kafadar, 2004); farklı ülkelerin sosyal bilgiler dersi öğretim programlarının değerler eğitimi boyutunda karşılaştıılması (Kafadar, Öztürk ve Katılmış, 2018) gibi birçok çalışma bulunmaktadır. 2018 sosyal bilgiler dersi öğretim programına yönelik bir çalışma da mevcuttur. Fakat bu çalışmada 2005 ve 2018 sosyal bilgiler dersi öğretim programlarındaki sadece kazanımlar değerlendirilmiştir (Oğuz Haçat ve Demir, 2018). İncelenen literatür içinde 2018 yılında yayınlanan sosyal bilgiler dersi öğretim programını bütüncül bir yaklaşımla değerlendirilmesine yönelik bir çalışmaya rastlanmamıştır. Araştırma bu yönüyle de alana önemli katkı sağlayacağı beklenmektedir.

Araştırmada 2018 yılında uygulanmaya başlanan sosyal bilgiler dersi öğretim program1 değerlendirilmek hedeflenmektedir. Bu amaçla aşağıdaki soruların cevabı aranmıştır? 
Sosyal bilgiler dersi öğretim programında;

$>$ Amaçlar nasıldır?

$>$ İçerik nasıldır?

$>$ Öğrenme öğretme süreçleri nasıldır?

$>$ Değerlendirme boyutu nasıldır?

\section{YÖNTEM}

\section{Araştırmanın Deseni}

$\mathrm{Bu}$ araştırma nitel araştırma modeline göre tasarlanmıştır. Araştırmada nitel araştırma desenlerinden ise durum çalışmasına göre planlanmıștır. Durumlar; bireyler, gruplar, kurumlar, kültürler, programlar, bölgeler, ulus-devletler ve mahalleler olabilir (Patton, 2014). Durumlar kişinin hayatı sürecinde veya bir programdaki önemli olaylar ya da sınırlandırılmış bir sistem olarak ifade edilen bir şey de olabilir (Stake, 2000'dan akt., Patton, 2014). Araştırmada 2018 yılında uygulanmaya başlanan sosyal bilgiler dersi öğretim programı bir durum olarak kabul edilmiş ve incelenerek değerlendirilmiştir.

\section{Verilerin Kaynağı}

Araştırmada amaçlı örnekleme yöntemine göre verilerin kaynağı belirlenmiştir. Amaçlı örnekleme yöntemi Patton'a (1987) göre zengin veriye sahip oldukları düşünülen durumların detaylı bir şekilde araştırılmasına imkan vermektedir (akt., Yıldırım ve Şimşek, 2011). Amaçlı örnekleme yöntemlerinden ise ölçüt örneklemesi kullanılmıştır. Araştırmada 2018 yılında uygulanmaya başlanan yeni sosyal bilgiler dersi öğretim programı verilerin kaynağını oluşturmuştur. 2018'de uygulamaya başlanan sosyal bilgiler öğretim programının verilerin kaynağı olarak belirlenmesinin nedeni programın tüm boyutlarının bütüncül bir yaklaşımla değerlendirilerek, son yayınlanmış olan bu programın eksikliklerini görme imkânı vermesi açısından bu program verilerin kaynağı olarak belirlenerek incelenmiştir.

\section{Verilerin Toplanması}

Araştırmada veriler doküman incelemesi aracılığıyla toplanmıştır. Nitel bir araştırmada doğrudan görüşme veya gözlemin olanaklı olmadığı durumlarda doküman incelemesi başka veri toplama teknikleri olmadan tek başına kullanılabilmektedir (Yıldırım ve Şimşek, 2011). Bu araştırmada Türkiye 2018 y1lında uygulanmaya başlanan sosyal bilgiler dersi öğretim program doküman olarak kullanılmıştır.

Araştırma verilerinin toplanması sürecinde takip edilen aşamalar şu şekildedir:

Dokümanlara ulaşma: Bu aşamada sosyal bilgiler dersi öğretim programına ulaşılmıştır. Sosyal bilgiler dersi programı MEB resmi web sitesinden erişilmiştir.

Orijinalliği kontrol etme: Öğretim programı Milli Eğitim Bakanlığı resmi web sitesi sayfasında yer almasından dolayı dokümanların orijinalliği bu şekilde test edilmiştir.

Dokümanları anlama: Araştırma dokümanlarının tek tek araştırma soruları ile ilişkilendirilmesi gerçekleştirilmiştir.

Veriden örneklem seçme: Bu çalışmada analiz yapılan metinlerde örnekleme yoluna gidilmeyip sosyal bilgiler öğretim programının tüm aşamaları tasnif edilmiştir.

Kategorilerin geliştirilmesi. Bu aşamada ilgili sorularla ilgili kategoriler geliştirilmiştir.

\section{Verilerin Analiz Edilmesi}

Araştırma verileri içerik analizi yöntemi ile analiz edilmiştir. Araştırmanın verileri analiz edilirken Yıldırım ve Şimşek (2011) tarafından tavsiye edilen aşağıdaki aşamalar izlenmiştir:

Verilerin kodlanması: $\mathrm{Bu}$ aşamada veriler incelenmiş ve kodlamalar gerçekleştirilmiştir. Program dört aşamada (amaçlar, içerik, öğrenme-öğretme süreci ve değerlendirme) incelenmiştir. Program incelenirken kullanılan aşamalar literatür incelemesi sonucunda öğretim programlarının genel 
olarak dört aşamadan (Erden, 2015) oluşması nedeniyle bu aşamalar kullanılmıştır. Amaçlar kısmında programın perspektif, amaçlar ve özel amaçlar, içerik kısmında öğrenme alanları, değerler, beceriler, öğrenme öğretme sürecinde programın yaklaşımı, değerlendirme kısmında ise ölçme değerlendirme yöntemleri incelenmiştir.

Temaların bulunması: $\mathrm{Bu}$ aşamada elde edilen kodlar bir araya getirilip incelenerek, ortak yönlerine göre bir araya toplanmıştır. Bu şekilde tematik kodlama gerçekleştirilmiştir.

Kodların ve temaların düzenlenmesi: Bu aşamada ise elde edilen kodlar uygun temalar altında düzenlenmiştir.

Bulguların tanımlanması ve yorumlanması: Elde edilen kodlar kategoriler altında bir araya getirilerek tablolar haline getirilmiş sonra tanımlama ve yorumlamalar yapılmıştır. Tablolarda nicel olarak ulașılan bulguların yoğunluklarını belirmek amacıyla tabloların altına $(f 5),(f 6)$, $(f 7)$ gibi tablolar tanımlanmıştır. Ayrıca verileri desteklemek için dokümanlardan örnek alıntılar seçilmiş ve bulguları açıklarken doğrudan alıntılarla desteklenmiştir.

\section{Geçerlik ve Güvenirlik}

Araştırmada geçerlik ve güvenirlik kapsamında yapılan işlemler şu şekildedir: Dokümanlara ulaşma aşamasında sosyal bilgiler dersi öğretim programı ülkenin eğitimle ilgili resmi web sitesinden ulaşılmıştır. Bu yolla dokümanların orijinallikleri test edilmiştir.

Araştırmanın verileri analiz edilme sürecinde ilk önce kodlamalar gerçekleştirilmiştir. Analiz sürecinde kodlamaların ve sınıflamaların doğru yapılıp yapılmadığına ilişkin araştırmacılar ilk önce birbirlerinden bağımsız daha sonra ise bir araya gelerek yaptıkları kodlamalar ve analizler arasındaki güvenirlik katsayısı hesaplanmıştır. Miles ve Huberman (1994) güvenirlik katsayısı 0,93'dür. Bu katsayı analizlerin güvenirliğinin yüksek olduğunu göstermektedir.

\section{BULGULAR}

Türkiye 2018'den itibaren uygulanmakta olan sosyal bilgiler dersi öğretim programının değerlendirildiği bu araştırmada ulaşılan bulgular şu şekildedir: Öğretim programında amaçlar; perspektif, amaçlar ve özel amaçlar olarak yer almaktadır. Öğretim programında perspektif incelendiği zaman ulaşılan bulgular Şekil 1' de gösterilmiştir.

Şekil 1. Öğretim programında perspektif

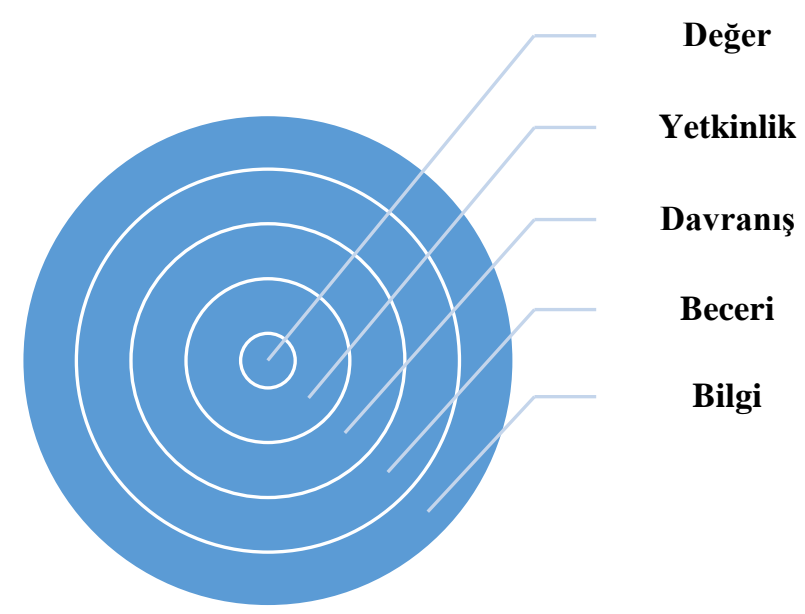

Şekil 1.'e göre öğretim programında sosyal bilgiler dersine ait ayrı bir perspektife sahip değildir. Öğretim programının perspektifi tüm dersler için genel olarak verilmiştir. Genel olarak öğretim programının perspektifi incelendiğinde; değerler ve yetkinlikler temelinde bilgi, beceri ve davranış kazandırmak hedeflenmektedir. 
Öğretim programının amaçları tüm dersler için okul öncesi, ilkokul, ortaokul ve lise olmak üzere dört düzeyde belirlenmiştir. Sosyal bilgiler dersleri ilkokul ve ortaokul düzeyleri ile ilgili olduğu için bu düzeyler incelenmiştir.

Tablo 1.1. Öğretim programında amaçlar

\begin{tabular}{|c|c|c|c|c|}
\hline 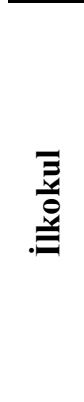 & $\begin{array}{l}\checkmark \\
\checkmark \\
\checkmark \\
\checkmark \\
\checkmark \\
\checkmark \\
\checkmark \\
\checkmark\end{array}$ & $\begin{array}{l}\text { Ahlaki bütünlük, } \\
\text { Öz farkındalı } \\
\text { Özgüven, } \\
\text { Özdisiplin, } \\
\text { Sözel, sayısal, bilimsel } \\
\text { yürütme, } \\
\text { Sosyal beceri, } \\
\text { Estetik duyarlılık } \\
\text { Sağllkl hayat yönelimli, }\end{array}$ & akıl & $\begin{array}{ll}\checkmark & \text { Milli manevi değerlerini } \\
& \text { benimseyen, } \\
\checkmark & \text { Beceri, } \\
\checkmark & \text { Yetkinlik kazanmış } \\
\checkmark & \text { Haklarını kullanabilen, } \\
\checkmark & \text { Sorumluluklarını yerine } \\
& \text { getirebilen, }\end{array}$ \\
\hline
\end{tabular}

Tablo 1.1. incelendiği zaman ulaşılan bulgular şu şekildedir: İlkokul düzeyi incelendiği zaman; ilkokulu tamamlayan öğrencilerin ahlaki bütünlük, öz farkındalık, özgüven, öz disiplin, sözel, sayısal, bilimsel akıl yürütme, sosyal beceri, estetik duyarlılık ve sağlıklı hayat yönelimli bireyler yetiştirmek hedeflenmektedir.

Ortaokul düzeyi incelendiği zaman ise; ortaokulu tamamlayan öğrencilerin ise milli manevi değerlerini benimseyen, beceri ve yetkinlikleri kazanmış, haklarını kullanabilen, sorumluluklarını yerine getirebilen bireyler yetiştirmek hedeflenmektedir.

Tablo 1.2. Sosyal bilgiler dersi öğretim programının özel amaçları

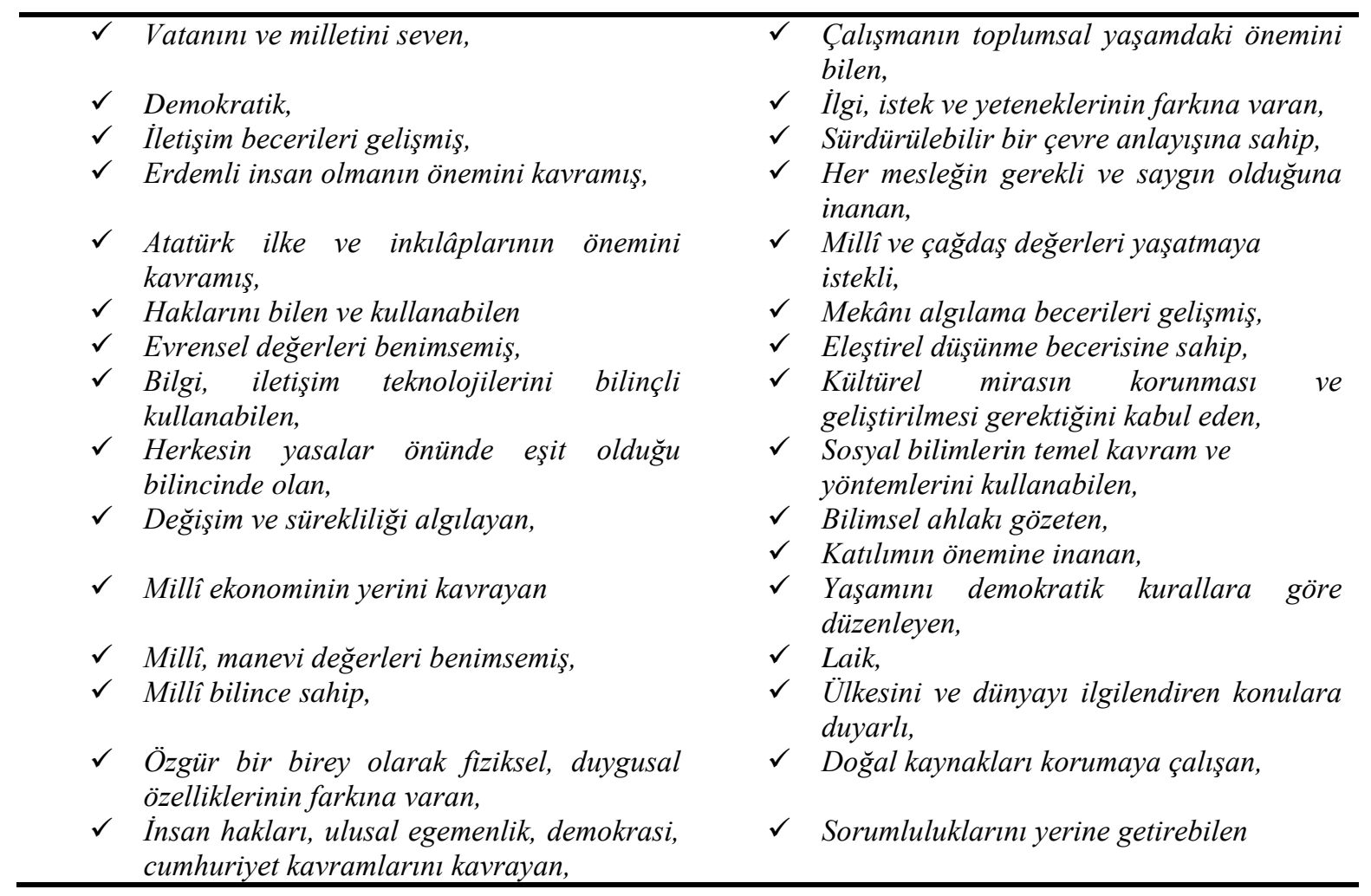

Tablo 1.2. incelendiği zaman sosyal bilgiler dersi öğretim programının özel amaçları olarak şu bulgulara ulaşılmıştır: 
Sosyal bilgiler dersi öğretim programında 18 özel amaç belirtilmektedir. Bu amaçlar incelendiği zaman sosyal bilgiler öğretim programında; "vatanını ve milletini seven, demokrasi ve cumhuriyet kavramlarını kavrayan, sorumluluklarını yerine getiren, Atatürk ilke ve inkllâplarının önemini kavramış, laik, millî ve çağdaş değerleri yaşatmaya istekli, kültürel mirasın korunması ve gelişstirilmesi gerektiğini kabul eden, sürdürülebilir bir çevre anlayışına sahip, temel iletişim becerilerini kullanabilen, millî, manevi değerleri benimseyen, erdemli insan olmanın önemini ve yollarını bilen, millî bilince sahip, demokratik, özgür bir birey olarak fiziksel, duygusal özelliklerinin farkına varan, haklarını bilen ve kullanan, doğal kaynakları korumaya çalışan, eleştirel düşünme becerisine sahip, millî ekonominin yerini kavrayan, çalışmanın toplumsal yaşamdaki önemini bilen, her mesleğin gerekli ve saygın olduğuna inanan, değişim ve sürekliliği algllayan, tüm kişsi ve kuruluşların yasalar önünde eşit olduğunu bilen, sosyal bilimlerin temel kavram ve yöntemlerini kullanabilen, bilgi ve iletişim teknolojilerini bilinçli kullanan, bilimsel ahlakı gözeten, katılımın önemine inanan, insan hakları, ulusal egemenlik, yaşamın demokratik kurallara göre düzenleyen, evrensel değerleri benimseyen, , mekânı algilama becerilerini gelişmiş, ülkesini ve dünyayı ilgilendiren konulara duyarl, ilgi, istek ve yeteneklerinin farkına varan" bireyler yetiştirmek amaçlanmaktadır.

2018 yılında yayınlanan sosyal bilgiler dersi öğretim programı içeriği öğrenme alanları, kazanımlar, değerler ve becerilerden oluşmaktadır.

Tablo 2.1. Sosyal bilgiler dersi öğretim programında öğrenme alanları

\begin{tabular}{|c|c|}
\hline 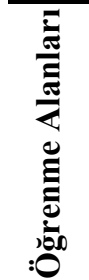 & $\begin{array}{l}\text { Birey ve Toplum } \\
\text { Kültür ve Miras } \\
\text { Insanlar, Yerler ve Çevreler } \\
\text { Bilim, Teknoloji ve Toplum } \\
\text { Üretim, Dağttım ve Tüketim } \\
\text { Etkin Vatandaşllk } \\
\text { Küresel Bağlantılar }\end{array}$ \\
\hline
\end{tabular}

Tablo 2.1. incelendiği zaman sosyal bilgiler öğretim programında "birey ve toplum, insanlar, yerler ve çevreler, üretim, dağıtım ve tüketim, bilim, teknoloji ve toplum, kültür ve miras, etkin vatandaşlık, küresel bağlantılar" olmak üzere yedi öğrenme alanı yer almaktadır.

Tablo 2.2. Sosyal bilgiler dersi öğretim programında kazanımlar

\section{Kazanımlar}

\begin{tabular}{lllll} 
Öğrenme Alanları & 4. sınıf & 5. sınıf & 6. sınıf & 7. sinıf \\
\hline Birey ve Toplum & 5 & 4 & 5 & 4 \\
Kültür ve Miras & 4 & 5 & 5 & 5 \\
Insanlar, Yerler ve Çevreler & 6 & 5 & 4 & 4 \\
Bilim, Teknoloji ve Toplum & 5 & 5 & 4 & 4 \\
Uretim, Dağıtım ve Tüketim & 5 & 6 & 6 & 6 \\
Etkin Vatandaşllk & 4 & 4 & 6 & 4 \\
Küresel Bağlantılar & 4 & 4 & 4 & 4 \\
& 33 & 33 & 34 & 31
\end{tabular}


Tablo 2.2. incelendiği zaman sosyal bilgiler dersi öğretim programında kazanımlara ilişkin şu bulgular elde edilmiştir:

Sosyal bilgiler dersi öğretim programında kazanımlar öğrenme alanları çerçevesinde yer almaktadır. Programda 4. sınıf; birey ve toplum öğrenme alanında (f5), "kültür ve miras" (f4), "insanlar, yerler ve çevreler" (f6), "bilim, teknoloji ve toplum" (f5), "üretim, dağıtım ve tüketim" (f5), "etkin vatandaşlık" (f4), "küresel bağlantılar" (f4) olmak üzere toplam (f33) kazanım yer almaktadır.

5. sınıf; "birey ve toplum" öğrenme alanında (f4), "kültür ve miras" (f5), "insanlar, yerler ve çevreler" (f5), "bilim, teknoloji ve toplum" (f5), "üretim, dağltım ve tüketim" (f6), "etkin vatandaşlık" (f4), "küresel bağlantılar" (f4) olmak üzere toplam (f33) kazanım yer almaktadır.

6. sınıf birey ve toplum öğrenme alanında (f5), "kültür ve miras" (f5), "insanlar, yerler ve çevreler" (f4), "bilim, teknoloji ve toplum" (f4), "üretim, dağıtım ve tüketim" (f6), "etkin vatandaşlık" $(f 6)$, "küresel bağlantılar" (f4) olmak üzere toplam (f34) kazanım yer almaktadır.

7. sınıf birey ve toplum öğrenme alanında (f4), "kültür ve miras" (f5), "insanlar, yerler ve çevreler" (f4), "bilim, teknoloji ve toplum" (f4), "üretim, dağltım ve tüketim" (f6), "etkin vatandaşlık" $(f 4)$, "küresel bağlantılar" (f4) olmak üzere toplam (f31) kazanım yer almaktadır.

Sosyal bilgiler dersi programında değerler eğitimi ayrı öğretim programı, konu alanı, ünite olarak değil eğitim sürecinin en önemli amacı olarak tüm süreçte yer aldığı ifade edilmektedir. Değerler perspektif bölümünde "kök değerler" olarak siralanmaktadır.

Tablo 2.3.1. Sosyal bilgiler dersi öğretim programının perspektifinde "kök değerler"

\begin{tabular}{|c|c|c|c|c|}
\hline 离 & $\begin{array}{l}\checkmark \\
\checkmark \\
\checkmark \\
\checkmark \\
\checkmark\end{array}$ & $\begin{array}{l}\text { Adalet } \\
\text { Sevgi } \\
\text { Sorumluluk } \\
\text { Yardımseverlik } \\
\text { Özdenetim }\end{array}$ & $\begin{array}{l}\checkmark \\
\checkmark \\
\checkmark \\
\checkmark \\
\checkmark\end{array}$ & $\begin{array}{l}\text { Dürüstlük } \\
\text { Saygl } \\
\text { Sabır } \\
\text { Dostluk } \\
\text { Vatanseverlik }\end{array}$ \\
\hline
\end{tabular}

Tablo 2.3.1 incelendiği zaman kök değerler "adalet, sevgi, sorumluluk, yardımseverlik, özdenetim, dürüstlük, saygl, sabır, dostluk, vatanseverlik" olarak ifade edilmektedir. Kök değerler Schwartz ve ark. (2012) tarafindan geliştirilen değerler sınıflamasına göre incelendiği zaman adalet (evrenselcilik-ilgi), sevgi, sorumluluk (iyilikseverlik-sevgi), dürüstlük, dostluk, yardımseverlik (iyilikseverlik-güvenirlik), özdenetim, sabır (uyma-kişilerarası), saygı (evrenselcilik-hoşgörü), vatanseverlik ise (güvenlik-toplumsal) değer tiplerinde yer almaktadır.

Tablo 2.3.2. Sosyal bilgiler dersi öğretim programında değerler

\begin{tabular}{|c|c|c|c|}
\hline$\checkmark$ & Adalet & $\checkmark$ & Eşitlik \\
\hline$\checkmark$ & Dürüstlük & $\checkmark$ & Saygl \\
\hline$\checkmark$ & Sorumluluk & $\checkmark$ & Duyarlılık \\
\hline$\checkmark$ & Bağımsızlık & $\checkmark$ & Sevgi \\
\hline$\checkmark$ & Vatanseverlik & $\checkmark$ & Sevgi \\
\hline$\checkmark$ & Bilimsellik & $\checkmark$ & Aile birliğine önem verme \\
\hline$\checkmark$ & Dayanışma & $\checkmark$ & Tasarruf \\
\hline$\checkmark$ & Estetik & $\checkmark$ & Yardımseverlik \\
\hline & Barış & $\checkmark$ & Çalışkanlık \\
\hline
\end{tabular}

2018 y1lında uygulanmaya başlanan sosyal bilgiler dersi öğretim programında kazandırılması hedeflenen değerlerin doğrudan sıralaması yapılmıştır. Bu değerler Tablo 2.3.2. de özetlenmektedir. Tabloda yer alan değerler incelendiği zaman şu bulgulara ulaşılmıştır: 
Sosyal bilgiler dersi öğretim programında "adalet, dürüstlük, sorumluluk, bağımsızlık, vatanseverlik bilimsellik, dayanışma, estetik, barış, eşitlik, saygl, duyarlılık, sevgi, aile birliğine önem verme, tasarruf, yardımseverlik, özgürlük ve çalışkanlık" değerlerinin kazandırılması hedeflenmektedir.

Tablo 2.4. Sosyal bilgiler dersi öğretim programında beceriler

\begin{tabular}{|c|c|c|}
\hline$\checkmark$ & Araştırma & $\checkmark \quad$ Yenilikçi düşünme \\
\hline$\checkmark$ & Dijital vatandaşlık & $\checkmark \quad$ Zaman ve kronolojiyi algilama \\
\hline$\checkmark$ & Sosyal katılım & $\checkmark \quad$ Çevre okuryazarliğı \\
\hline$\checkmark$ & Eleştirel düşünme & $\checkmark \quad$ Politik okuryazarlık \\
\hline$\checkmark$ & Finansal okuryazarlık & $\checkmark \quad$ Empati \\
\hline$\checkmark$ & Konum analizi & $\checkmark \quad$ Problem çözme \\
\hline$\checkmark$ & Gözlem & $\checkmark \quad$ Kalıp yargl ve önyarglyı fark etme \\
\hline$\checkmark$ & Harita okuryazarlı̆̆ & $\checkmark \quad$ Hukuk okuryazarlı̆̆ \\
\hline$\checkmark$ & Türkçeyi doğru, güzel ve etkili kullanma & $\checkmark \quad \ddot{\text { zdenetim }}$ \\
\hline$\checkmark$ & Iletişim & $\checkmark \quad$ Tablo, grafik ve diyagram çizme ve yorumlama \\
\hline$\checkmark$ & $\dot{I}_{\text {Şbirliğ } i}$ & $\checkmark$ Girişimcilik \\
\hline$\checkmark$ & Kanit kullanma & $\checkmark \quad$ Mekânı algılama \\
\hline$\checkmark$ & Karar verme & $\checkmark \quad$ Değişim ve sürekliliği algılama \\
\hline & Medya okuryazarlı̆̆ & \\
\hline
\end{tabular}

Tablo 2.4. göre 2018 yılında yayınlanan sosyal bilgiler dersi öğretim programında beceriler incelendiği zaman şu bulgulara ulaşılmıştır:

Programında temel beceriler olarak; "araştırma, dijital vatandaşlık, sosyal katılım, eleştirel düşünme, finansal okuryazarlık, konum analizi, gözlem, harita okuryazarlı̆̆l, Türkçeyi doğru, güzel ve etkili kullanma, iletişim, işbirliği, kanıt kullanma, karar verme, medya okuryazarlı̆̆l, yenilikçi düşünme, zaman ve kronolojiyi algılama, çevre okuryazarliğl, politik okuryazarlık, empati, problem çözme, kalıp yargl ve önyarglyı fark etme, hukuk okuryazarlığı, özdenetim, tablo, grafik ve diyagram çizme ve yorumlama, girişimcilik, mekanı algılama ve değişim ve sürekliliği algılama, " becerilerinin kazandırılması hedeflenmektedir.

Tablo 3. Sosyal bilgiler dersi öğretimi programının yaklaşımı

\begin{tabular}{ll}
\hline Harmonik & Ö̆̆renme alanlarına dayalı \\
Çokdisiplinli & Değer temelli \\
Genelden özele & Yetkinlikler temelli \\
Somuttan soyuta & Bilgi \\
Basitten karmaşı̆̆a & Beceri \\
Bütünsel & Davranış \\
Öğrenci merkezli & \\
\hline
\end{tabular}

Tablo 3'e gore sosyal bilgiler dersi öğretim programında harmonik, çokdisiplinli, genelden özele, somuttan soyuta, basitten karmaşığa, bütünsel, öğrenci merkezli, öğrenme alanlarına dayalı, değer ve yetkinlikler temelli, bilgi, beceri ve davranış kazandırmayı hedefli bir yaklaşım benimsenmektedir.

Tablo 4. Sosyal bilgiler dersi öğretim programında değerlendirme

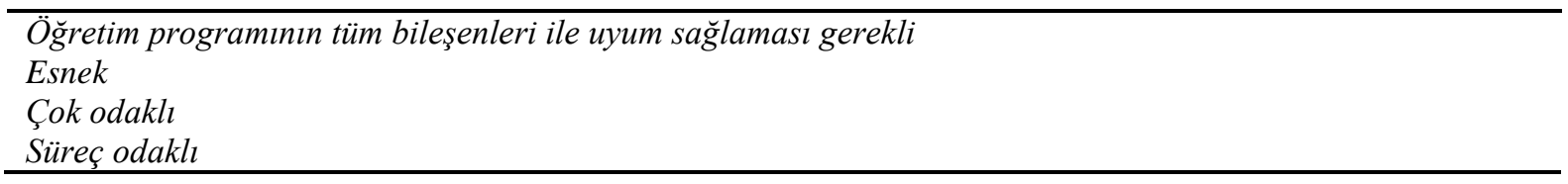


Tablo 4'a göre sosyal bilgiler dersi programı incelendiği zaman değerlendirme boyutu olarak; öğretim programının tüm bileşenleri ile uyum sağlaması gerektiği, esnek, çok odaklı ve süreç odaklı ölçme değerlendirme yaklaşımının benimsenmesi gerektiği ifade edilmektedir.

\section{TARTIŞMA, SONUÇ VE ÖNERILER}

2018 yılında yayınlanmış olan Türkiye sosyal bilgiler dersi öğretim programı bütüncül bir yaklaşımla değerlendirildiğinde ulaşılan sonuçlar şu şekildedir: Sosyal bilgiler dersi programı dört boyutta değerlendirilmiştir. Öğretim programı incelendiği zaman amaçlar boyutunda perspektif, amaçlar ve özel amaçlardan oluşmaktadır.

Sosyal bilgiler dersi öğretim programı derse ait ayrı bir perspektife sahip değildir. Programın perspektifi tüm dersler için genel olarak verilmiştir. Programın perspektifinde değerler ve yetkinlikler temel alınarak bilgi, beceri ve davranış kazandırmak amaçlanmaktadır. Perspektifle programın en genel hedefleri ifade edilmektedir. 2005 yılında yayınlanan sosyal bilgiler dersi öğretim programında perspektif vizyon olarak adlandırılmıştır. Farklı ülkelerin programlarını incelediğimiz zaman da Fransa programında (Ministére De Léducation Nationale, 2015) genel prensipler (principes généraux) olarak ifade edilmektedir. Bu sonuçlar programlarda benzer amaçlar taşıyan bölümlerin ülkeden ülkeye veya aynı ülkede farklı zamanlarda benzer isimlerle adlandırıldığını göstermektedir.

2005 yılında yayınlanan sosyal bilgiler dersi öğretim programının vizyonu incelendiği zaman genel olarak bilgi, beceri, değer ve davranış kazandırmak hedeflenmektedir. Farklı ülkelerin sosyal bilgiler dersi öğretim programlarını incelediğimiz zaman da NCSS (2010) ve ABD (New York) (2016) programlarında bilgi, beceri, değer ve davranış kazandırmak hedeflenmektedir. $\mathrm{Bu}$ sonuçlar Türkiye'nin 2018 yılında yayınlanan sosyal bilgiler dersi öğretim programıla benzer hedefler içermektedir.

Programda değerler, köklerinin geçmişten günümüze kadar uzanarak temel insani özelliklerimizi oluşturmak ve günlük hayatımızdaki sorunlarımızı çözmedeki gücün kaynağı olarak ifade edilmektedir. Değerler eğitimi 2018 sosyal bilgiler dersi öğretim programında ayrı bir konu alanı, ünite olarak değil eğitim sürecinin en önemli amacı olarak tüm süreçte yer aldığı ifade edilerek programın perspektifinde kök değerler "(adalet, dostluk, sevgi, sorumluluk, dürüstlük, yardımseverlik, özdenetim, sabır, saygl, vatanseverlik)" ifade edilmektedir. 2018 yılında uygulanmaya başlanan sosyal bilgiler öğretim programında değerler programın en önemli parçası olarak kabul edilmektedir Değerlerin toplum için neden önemli olduğu konusunda Harland ve Pickering (2011) bireylerin yaşamlarını doğru bir şekilde sürdürebilmeleri için doğruyu ve yanlışı ayırt etmek için kullandıkları ölçütler olarak ifade etmektedir. Öztürk ve Kafadar (2019) da değerleri toplumların bireyleri arasında birleştirici rol oynayan ve toplumların devamlılı̆̆ını sağlayan öğeler olarak nitelendirmişlerdir. Yine bir diğer araştırmacı değerlerin insan hayatı için çok önemli olduğu ve topluma zarar vermeyen, insan sağlığını destekleyen her şey olduğunu belirtmiştir (Zecha, 2007). Yapılan araştırmalar değerlerin toplumların varlıklarını sürdürebilmeleri için çok önemli öğeler olduğu yönündedir. 2018 yılında uygulanmaya başlanan sosyal bilgiler dersi öğretim programında da değerler eğitimine önem verildiği ifade edilerek programın tüm sürecine yayılmıştır.

Beceriler programda yetkinlikler çerçevesinde yer almaktadır. Yetkinlikler; "anadilde iletişim, matematiksel yetkinlik ve bilim/teknolojide temel yetkinlikler, sosyal ve vatandaşlıkla ile ilgili yetkinlikler, öğrenmeyi ögrenme, inisiyatif alma ve girişimcilik, yabancı dillerde iletişim, dijital yetkinlik, kültürel farkındalık ve ifade" olarak yer almaktadır. Yetkinlikler Türkiye Yeterlilikler Çerçevesinde (TYÇ) belirlenmiştir. "Türkiye Yeterlilikler Çerçevesi Avrupa Yeterlilikler Çerçevesine" uygun hazırlanmıştır (TYÇ, 2015). Sosyal bilgilerin disiplinlerarası yapısı göz önünde bulundurulduğunda "anadilde iletişim, bilim/teknolojide temel yetkinlikler, sosyal ve vatandaşlikla ilgili yetkinlikler, öğrenmeyi öğrenme, inisiyatif alma ve giriş̧imcilik, yabancı dillerde iletişim, dijital yetkinlik, kültürel farkındalık ve ifade" sosyal bilgilerle ilişkili yetkinliklerdir. Fakat "matematiksel yetkinlik" sosyal bilgiler ile ilgili yetkinlik değildir. Bu bağlamda programda yetkinliklerin bir bütün içinde vermek yerine sosyal bilgiler ile ilgili yetkinliklerin verilmesi daha uygun olabilir.

Amaçlar programda okul öncesi, ilkokul, ortaokul ve lise olarak dört boyutta ifade edilmektedir. Sosyal bilgiler dersleri ilkokul ve ortaokul düzeylerinde eğitimi verildiği için bu düzeyler incelenmiştir. İlkokulu tamamlayan öğrencilerin "ahlaki bütünlük, öz farkındalık, özgüven, öz disiplin, sözel, saylsal, bilimsel akl yürütme, sosyal beceri, estetik duyarlılık ve sağllkl hayat yönelimli" bireyler olarak 
yetişmesi amaçlanmıştır. Ortaokulu tamamlayan öğrencilerin ise "milli manevi değerleri benimseyen, beceri ve yetkinlikleri kazanmış, sorumluluklarını yerine getirebilen, haklarını kullanabilen" bireyler olarak yetişmesi amaçlanmıştır. Bir önceki Türkiye sosyal bilgiler dersi öğretim programı olan 2005 yılında yayınlanan programda ise genel amaçlar sınıf düzeylerine göre değil bir bütün olarak verilmiştir. Her iki programı karşılaştırmalı olarak incelediğimiz zaman 2018 sosyal bilgiler dersi öğretim programının dört düzeyde verilmesi, sosyal bilgiler eğitiminin "çocuğa görelilik" ilkesine göre verilmesini amaç edinildiğini göstermektedir. Bu durum sosyal bilgiler eğitiminin etkili bir şekilde verilmesi açısından olumlu katkı sağlayabilir.

Sosyal bilgiler dersi öğretim programı özel amaçları incelendiği zaman; "vatanını ve milletini seven, demokratik, laik, millî ve çağgdaş değerleri yaşatmaya istekli, tüm kişi ve kuruluşların yasalar önünde eşit olduğunu bilincinde olan, temel iletişim becerilerini kullanabilen, Atatürk ilke ve inkalâplarının önemini kavramış, her mesleğin gerekli ve saygın olduğuna inanan, sosyal bilimlerin temel kavram ve yöntemlerini kullanabilen, hakların bilen ve kullanabilen, , milli bilince sahip, özgür bir birey olarak fiziksel, duygusal özelliklerinin farkına varan, mekânı algılama becerileri gelişmiş, doğal kaynakları korumaya çalışan, sürdürülebilir bir çevre anlayışına sahip, millî ekonominin önemini kavramış, değişim ve sürekliliği algılayan, sorumluluklarını yerine getirebilen, bilgi ve iletişim teknolojilerini bilinçli kullanan, kültürel mirasın korunması ve geliştirilmesi gerektiğini kabul eden, millî, manevi değerleri benimseyen, bilimsel ahlakı gözeten, katılımın önemine inanan, erdemli insan olmanın önemini ve yolların bilen, insan haklart, ulusal egemenlik, demokrasi ve cumhuriyet kavramlarını kavrayan, yaşamını demokratik kurallara göre düzenleyen, eleştirel düşünme becerisine sahip, çalışmanın toplumsal yaşamdaki önemini bilen, evrensel değerleri benimseyen, ülkesini ve dünyay ilgilendiren konulara duyarl, ilgi, istek ve yeteneklerinin farkına varan" bireyler yetiştirmek amaçlanmaktadır. Bu programın özel amaçları 2005 yılında yayınlanan sosyal bilgiler dersi programı genel amaçlarıyla neredeyse çoğu birebir aynıdır. Fakat "temel iletişim becerileri kullanabilen, eleştirel düşünme becerisine sahip, millî, manevi değerleri benimseyen, erdemli insan olmanın önemli olduğunu kavramış, doğal kaynakları korumaya çalışan, sürdürülebilir çevre anlayışına sahip, evrensel değerleri benimseyen" bireyler yetiştirmek amaçları 2005 yılında yayınlanan sosyal bilgiler dersi programının amaçlarında yer almamaktadır. Bu son eklenen amaçların 2005 yılında yayınlanan sosyal bilgiler dersi öğretim programında yer almaması önemli bir eksiklik oluştururken, son yayınlanan sosyal bilgiler dersi öğretim programına eklenmesi yaşadığımız küresel dünyada etkin, üretken bireyler yetişmesi için önemlidir. Çünkü yaşadığımız yüzyılda bireysel ve toplumsal olarak varlığımızı sürdürebilmemiz, toplumumuza, dünyaya olumlu katkılar getirebilmemiz için bu amaçlar bireyler için önemli beceri ve değer anlayışlarını oluşturmaktadır.

Sosyal bilgiler dersi öğretim programında "birey ve toplum, kültür ve miras, insanlar, yerler ve çevreler, bilim, teknoloji ve toplum, üretim, dağıtım ve tüketim, etkin vatandaşlık, küresel bağlantılar" öğrenme alanları yer almaktadır. Öğrenme alanları 2005'de yayınlanan sosyal bilgiler dersi programında olan öğrenme alanlarıyla karşılaştırıldığı zaman farklı olarak "zaman süreklilik ve değişim, güç, yönetim ve toplum, gruplar, kurumlar ve sosyal örgütler ile" öğrenme alanları da önceki öğretim programında yer almaktadır. 2018'de yayınlanmış olan sosyal bilgiler dersi programında ise farklı olarak "etkin vatandaşlık" öğrenme alanı yer almaktadır. 2005'de yayınlanmış olan sosyal bilgiler dersi programına göre öğrenme alanlarının azaltıldığı görülmektedir. 2005'de yayınlanmış olan sosyal bilgiler dersi programının öğrenme alanlarına göre yeni programa “etkin vatandaşlık” öğrenme alanının eklenmesi sosyal bilgilerin etkin vatandaşlar yetiştirmek temel amacında olduğu göz önüne alındığında yerinde bir karar olmuştur. Fakat 2018'de yayınlanmış olan sosyal bilgiler dersi programının öğrenme alanlarında "zaman süreklilik ve değişim" öğrenme alanının yer almaması büyük bir eksiklik oluşturmaktadır. Çünkü bireyin ve toplumların geçirdiği tarihsel geçmişi öğrenmesi şu anı anlamlandırabilmesi için gereklidir. Ayrıca programın özel amaçlarında "değiş̧im ve sürekliliği algılamak" ile ilgili amaç bulunması öğrenme alanlarıyla tezatlık oluşturmaktadır. NCSS'e (2010) göre sosyal bilgiler dersi programları, geçmişin ve mirasının çalışmasını sağlayan deneyimleri içermelidir. Geçmişi incelemek zamanla insan hikâyesini anlamamızı sağlar. Toplumların, halkların ve ulusların tarihsel deneyimleri süreklilik ve değişim kalıplarını ortaya koymaktadır. Tarihsel analiz, temel kurumlarda, değerlerde, ideallerde ve geleneklerde zaman içinde sürekliliklerin yanı sıra toplumlar ve kurumlar arasında değişime yol açan ve yenilik ve yeni fikirlerin, değerlerin ve yaşam biçimlerinin gelişmesine yol açan süreçleri tanımlamamızı sağlar. Geçmişi bilmek ve anlamak, olayların ve gelişmelerin nedenlerini ve sonuçlarını analiz etmemizi ve bunları, gerçekleştikleri dönemin kurumları, 
değerleri ve inançları bağlamına yerleştirmemizi sağlar. Geçmişi incelemek, insanların kendilerini, toplumlarını ve daha geniş dünyayı farklı zaman dilimlerinde nasıl gördüklerini bilmemizi sağlar. NCSS'in (2010) de "zaman süreklilik ve değişim" sosyal bilgiler temaları içerisinde yer alması ve bu şekilde açıklamalarda bulunması bu öğrenme alanının sosyal bilgiler için ne kadar önemli olduğunu gösteren kanıtlardır. NCSS (2010) sosyal bilgiler temaları ise "kültür, bireysel gelişim ve kimlik, bilim, teknoloji ve toplum, bireyler, gruplar ve kurumlar, küresel bağlantılar, insanlar, yerler ve çevreler, üretim, dağıtım ve tüketim, güç, otorite ve yönetim, zaman, süreklilik ve değişim, vatandaşlık hedefleri ve uygulamalarıdı". NCSS (2010) sosyal bilgiler temaları ile 2018 yılında yayınlanan sosyal bilgiler öğrenme alanları büyük oranda benzerlikler içermektedir. Bu sonuçlar ayrıca ABD sosyal bilgiler eğitim sisteminin Türkiye sosyal bilgiler eğitim sistemi üzerinde etkisini gösteren sonuçlardır.

Programda kazanımlar; öğrenme alanları çerçevesinde yer alarak genel olarak nicel olarak tüm sınıf düzeylerinde ve öğrenme alanlarında birbirine yakın paralel ilerlemektedir. En fazla 6. sınıf düzeyinde olmakla birlikte 4. ve 5. sinıf düzeylerinde aynı 7. sınıf düzeyinde ise en az kazanım yer almaktadır. Programda her bir öğrenme alanında yer alan kazanımların sayılarının sınırlı olduğu görülmektedir. Ayrıca bazı kazanımlar hakkında açıklamalar bulunurken bazılarında ise yer almamaktadır. Kazanımların sayı olarak sınırlı olması ve yeterince açıklamalar bulunmaması her bir kazanımın ve öğrenme alanının etkili bir şekilde kazandırılmasını kısıtlayabilir.

Okullar, bireylerin yaşadıkları toplumda veya diğer toplumlarda tam olarak vatandaş rollerini oynayabilmeleri için ihtiyaç duyacakları bilgi, beceri, tutum ve eğilimleri kazandırmaları gerektiği düşüncesiyle eğitimde hareket etmelidirler (Costello, 2005). Bu doğrultuda öğretim programlarında da aynı düşünceyle tasarlanmalıdır. Türkiye 2018 yılında yayınlanan sosyal bilgiler dersi öğretim programı değer temelli olduğu ifade edilerek perspektifte kök değerler olarak değerler sıralanmıştır. Bu değerler Schwartz ve ark. (2012) değer sınıflamasına göre sınıflandırıldığı zaman büyük oranda özaşkınlık değer boyutunda değerler yer almaktadır. Özaşkınlık kavram olarak; bireyin grup içinin güvenilir, inanılır üyesi olması ve kendi dışındaki bireylerin ve varlıkların korunmasına, iyiliğine, kabulüne kendini adamasidır (Schwartz ve ark., 2012).

Değerler eğitimi ise programda ayrı bir ders, konu alanı olarak değil tüm derslerle bütünleşik olarak verilmektedir. Değerler eğitimi Aspin'e (2007) göre ülkelerin öğretim programlarının en önemli unsuru olarak mutlaka yer almalıdır. Ayrıca programda kazandırılması hedeflenen değerlerin doğrudan sıralaması yapılmıştır. Bu değerler; "vatanseverlik, bağımsızlık, sorumluluk, çalışkanlık, dürüstlük, aile birliğine önem verme, eşitlik, sevgi, duyarlılık, adalet, dayanışma, estetik, barış, saygl, tasarruf, bilimsellik, özgürlük ve yardımseverliktir”. Bir önceki sosyal bilgiler dersi öğretim programında yer alan doğrudan değerler içerisinde eşitlik ve tasarruf değerleri yer almazken, önceki programda sağglkll olmaya önem verme, hoşgörü, temizlik ve misafirperverlik değerleri 2018 programında doğrudan verilen değerler içerisinde yer almamıştır. Bu değerlerden özellikle hoşgörü değerinin programın doğrudan verilen değerler içerisinde yer alması önemlidir. Değerler programda öğrenme alanları bağlamında belirtilmiş fakat bunların hangi kazanımla ilişkili olduğu açıklanmamıştır. Bu tercih söz konusu ilişkilendirmenin öğretmene bırakıldığ 1 şeklinde yorumlanabilir. Öğretmenden beklenen okul temelli program geliştirme anlayışıyla oluşturulacak eğitim durumlarında adı geçen değerlerin uygun konu/zamanda uygulanmaya taşınmasıdır. Ancak bunun hiç de kolay olmadığı ve uygulamada kâğıt üzerine kalma olasılığının yüksek olduğu düşünülmektedir. Bu durum bir önceki 2005 sosyal bilgiler dersi programında da benzer şekildedir. Ayrıca 2018 sosyal bilgiler dersi programında değerlerin nasıl kazandırılacağına dair değer öğretim yaklaşımlarına yer verilmemektedir. Bu bağlamda programda değerlerin öğretiminin yüzeysel kalındığı ifade edilebilir.

Programda temel becerilerin; "değişim ve sürekliliği algllama, iletişim, empati, tablo, grafik ve diyagram çizme ve yorumlama, girişimcilik, gözlem, hukuk okuryazarlığı, çevre okuryazarlığı, kanıt kullanma, eleştirel düşünme, karar verme, medya okuryazarlı̆̆ı, yenilikçi düşünme, mekanı algılama, dijital vatandaşlık, zaman ve kronolojiyi algılama, özdenetim, politik okuryazarlı, problem çözme, sosyal katılım, kalıp yargl ve önyarglyı fark etme, finansal okuryazarlık, araştırma, işbirliği, Türkçeyi doğru, güzel ve etkili kullanma, harita okuryazarlığı ve konum analizi" olduğu ifade edilmektedir. Beceriler yetkinlikler çerçevesinde belirtilmiş fakat hangi becerinin hangi yetkinlikle ilişkilendirileceği açıkça ifade edilmemektedir. Programda her öğrenme alanında kazandırılması hedeflenen beceriler belirtilmiş fakat hangi becerinin hangi kazanımla ilişkilendirileceği açıklanmamaktadır. Ayrıca öğrenme alanlarında etkinlik örnekleri yer almaması nedeniyle beceri öğretiminde eksiklikler bulunmaktadır. ABD'de 2002 y1lında kurulan Partnership for 21st century Learning (P21), daha 
önceden ise Partnership for 21st Century Skills isminde olarak, 21. yy. vatandaşlık eğitimi için temel becerilerin öğrencilere kazandırılması gerektiğini öne sürmüşlerdir. Bu beceriler şu şekildedir: "1) Yaratıcılık ve yenilik, 2)İşbirliği becerileri, 3) Eleştirel düşünme ve problem çözme, 4) Illetişim, " (P21, 2016). Vatandaşlık Komisyonu (1990) ise; aşağıdaki becerileri ve deneyimleri etkin vatandaşlık için gerekli olduğunu ileri sürmüştür: a) Tutarlı bir bakış açısını tartışabilme ve sunma kapasitesi, b) Seçimlere katılım, c) Başkalarını temsil ederek sorumluluk almak, örneğin bir okul konseyi için, d) İşbirliği içinde çalışmak, e) Bir takımın üyesi olmak, f) Örneğin bir gazeteye, belediye meclisine veya yerel dükkana yazarak protesto yapmak (Rogers 1992'dan akt., Costello, 2005). Türkiye sosyal bilgiler dersi öğretim programı uluslararası literatürle karşılaştırmalı olarak incelendiği zaman daha ayrıntılı beceriler yer almaktadır. Programda becerilerin sadece isimleri belirtilmiş bu becerilere ait açılayıcı bilgiler yer almamaktadır. Sosyal bilgiler dersi programında bulunan beceriler uluslararası literatürle karşılaştırılarak incelendiği zaman daha zengin bir yapıda olduğu ifade edilebilir.

Sosyal bilgiler dersi programının öğrenme-öğretme sürecinde; harmonik, çok disiplinli, genelden özele, somuttan soyuta, basitten karmaşığa, bütünsel, öğrenci merkezli, öğrenme alanlarına dayalı, değer ve yetkinlikler temelli, bilgi, beceri ve davranış kazandırmayı hedefli bir yaklaşım benimsendiği ifade edilebilir. 2005 yılında yayınlanan sosyal bilgiler dersi öğretim programı ise program yaklaşımı olarak öğrenci merkezli, toplu öğretim, öğrenme alanlarına dayalı yaklaşım, sarmal, genişleyen çevre yaklaşımı, ünite temelli, disiplinler arası, bilgi, kavram, beceri ve değer kazandırma hedeflidir. 2018 yılında yayınlanan sosyal bilgiler dersi öğretim programı açıklamalarında programın disiplinler arası olduğu açıklanmıştır. Fakat program incelendiği zaman disiplinler arası değil çok disiplinli bir yapıda olduğunu ifade edebiliriz. Programın yaklaşımı 2005 yılında yayınlanan sosyal bilgiler dersi programıyla genel olarak benzerlikler içermesine rağmen bazı farklıklarda bulunmaktadır. Önceki programda disiplinler arası yaklaşım benimsenmiştir. NCSS (2010) sosyal bilgiler dersi programının disiplinler arası olması gerektiğini açıklamıştır. Fakat son yıllarda yayınlanan ve revize edilen ABD (New York State Education Department, 2016), Fransa (Ministére De Léducation Nationale, 2015) gibi ülkelerin programlarında da çok disiplinli bir anlayışın hâkim olduğu ifade edilebilir.

Değerlendirme boyutu; her bireyin birbirinden farklı olduğu ilkesine dayanarak zami çeşitlilik ve esneklik anlayışı ile hareket edilmiştir. Bu doğrultuda ölçme değerlendirme sürecinin programın bütün bileşenleri ile uyum sağlaması gerektiği ifade edilmektedir. Programda çok odaklı ve süreç odaklı ölçme değerlendirme yaklaşımı benimsendiği ifade edilmektedir. Programda ölçme değerlendirme olarak temel ilkeler belirtilmiş fakat hangi ölçme değerlendirme yöntem ve tekniklerinin kullanılacağına dair açıklamalar bulunmamaktadır. 2005 yılında yayınlanan sosyal bilgiler dersi programında değerlendirme yöntemleri olarak, "sözlü sunum, kavram haritaları, görüşme, akran değerlendirme, gözlem, çoktan seçmeli testler, performans değerlendirme, öz değerlendirme, tutum ölçekleri, dereceli puanlama anahtarl, uzun cevapl maddeler, projeler, portfolyo, klsa cevaplı maddeler ve eşleştirmeli maddeler" verilmiştir.

Araştırma sonuçlarından yola çıkılarak şu öneriler getirilebilir:

2018 yılında yayınlanan sosyal bilgiler dersi öğretim programı değerlendirildiğinde program içeriğinde her öğrenme alanına ilişkin sadece kazanımlar ve açıklamaları bulunmaktadır. Kazanımlar ve açıklamaların ise yeterli sayıda yer almadığ 1 görülmektedir. Her bir öğrenme alanının etkili bir şekilde verilmesi için kazanım sayılarının artırılması ve kazanımların ise yeterince anlaşılması için açıklamalarının yeterli bir şekilde yenilenecek olan sosyal bilgiler dersi öğretim programında yer alması önemlidir. Ayrıca program içeriğinde etkinlik örnekleri yer almamaktadır. Etkinlik örneklerinin yer almaması program içeriğinin daha etkin öğretilmesi açısından büyük bir eksiklik oluşturabilir. Son süreçte yayınlanan Fransa, ABD (New York) dünyadan program içeriklerini incelediğimiz zaman daha fazla etkinlik yönelimli hazırlandığını görmekteyiz. Bu nedenle revize edilecek yeni sosyal bilgiler dersi öğretim programına etkinlik örneklerinin eklenmesi programın etkililiğini daha da artırabilir.

Öğretim programının değerleri temel alınarak programda tüm sürece yayıldığı ifade edilmektedir. Fakat program incelendiği zaman değerler sadece doğrudan sıralaması yapılmıştır. Değerlerin hangi kazanımla ilişkili olduğu ve nasıl öğretileceğine dair bilgiler bulunmamaktadır. Bu nedenle değerler eğitiminin daha etkin verilmesine ilişkin her bir kazanımda hangi değerin kazandırılmak hedeflendiğine ve bağlantılı etkinlik örnekleriyle ilişkilendirilmesi programa eklenebilir. Ayrıca değer öğretim yaklaşımlarının eklenmesi de değerler eğitimini daha etkin hale getirebilir.

Beceri eğitimi de değerler eğitimi gibi programda sadece doğrudan sıralaması yapılmaktadır. Programda beceriler yetkinliklerle ilişkilendirilmiş fakat hangi yetkinliğin hangi beceri ile ilişkili 
olduğu net olarak ifade edilmemektedir. Bu bağlamda her bir yetkinliğin hangi beceri ile ilişkili olduğu açık bir şekilde ifade edilebilir. Ayrıca program içeriğinde yer alan kazanımlarla hangi beceri kazandırılmak hedeflendiği açıkca ifade edilebilir.

Sosyal bilgiler dersi öğretim programı içeriğinde sadece ne öğretileceğine dair bilgiler bulunmaktadır. Fakat farklı ülkelerden program örnekleri incelendiği zaman, son yıllarda nasıl ve niçin öğretileceğine dair açıklamalar da bulunmaktadır. Bireylerin neyi neden öğrendiğine dair bilinçli olarak yetişmelerinde önemli katkı sağlayacağı düşünüldüğünde içerik kısmına bu tür bölümlerin eklenmesi önemli olabilir.

Programda değerlendirme bölümü olarak ölçme değerlendirme yöntemleri bulunmamaktadır. Yenilenen sosyal bilgiler dersi öğretim programına ölçme değerlendirme yöntemlerinin eklenmesi sosyal bilgiler eğitiminin daha etkin verilmesine katkı sağlayacaktır.

\section{KAYNAKÇA}

Akdağ, H. (2009). İlköğretim 6. ve 7. sınıf sosyal bilgiler öğretim programının öğrenci görüşlerine göre değerlendirilmesi (Konya İli Örneği). Selçuk Üniversitesi Sosyal Bilimler Enstitüsü Dergisi, (21), 1-14.

Algan, S. (2008). İlköğretim 6. ve 7. sinıf sosyal bilgiler dersi ögrretim programının ölçme ve değerlendirme öğesinin ögrretmen görüşleri açısından incelenmesi. (Yayınlanmamış Yüksek Lisans Tezi). Çukurova Üniversitesi, Adana.

Arslan, A. ve Demirel, Ö. (2007). İlköğretim 5. sınıf sosyal bilgiler dersi yeni öğretim programının değerlendirilmesi. Milli Eğitim Dergisi, 175, 198-209.

Aspin, D. N. (2007). The ontology of values and values education. In D. N. Aspin \& J. D. Chapman (Eds.) Values education and lifelong learning: Principles policies, programmes (pp. 27-48). Springer.

Ayten, P. (2006). İlkögretim okullarında sosyal bilgiler dersini yürüten 4. ve 5. sinlf ögretmenlerinin sosyal bilgiler dersi öğretim programına ilişskin görüşleri. (Yayınlanmamış Yüksek Lisans Tezi). Gazi Üniversitesi, Ankara.

Balcı, F. A. ve Yelken, T. Y. (2013). İlköğretim sosyal bilgiler programında yer alan değerler ve değer eğitimi uygulamaları konusunda öğretmen görüşleri. Ahi Evran Üniversitesi Kırşehir Eğitim Fakültesi Dergisi, $14(1), 195-213$.

Barr, H. (1997). Defining social studies. Teachers and curriculum, 1(1), 6-12.

Costello, P. J. M. (2005). Citizenship education, cultural diversity and the development of thinking skills. In M. Leicester, C. Modgil \& S. Modgil (Eds.), Education, culture and values Volume VI Politics, education and citizenship (pp. 176-195). London: Falmer Press.

Çoban, O., ve Akşit, İ. (2018). 2005 ve 2017 sosyal bilgiler öğretim programlarının öğrenme alanı, kazanım, kavram, değer ve beceri boyutları açısından karşılaştırılması. Journal of History Culture and Art Research, 7(1), 479-505. DOI: 10.7596/taksad.v7i1.1395.

Doğanay, A. (2008). Çağdaş sosyal bilgiler anlayışı 1şı̆ı̆ında yeni sosyal bilgiler programının değerlendirilmesi. Çukurova Üniversitesi Sosyal Bilimler Enstitüsü Dergisi, 17(2), 77-96.

Doğanay, A., ve Sarı, M. (2008). Öğretmen gözüyle yeni sosyal bilgiler programı: Adana ilinde bir araştırma. İlkögrretim Online, 7(2), 468-484.

Doğanay, A. (2009). Değerler eğitimi. C. Öztürk (Ed.), Sosyal bilgiler öğretimi demokratik vatandaşlık eğitimi (s. 225-256). Ankara: Pegem Akademi.

Erden, M. (2015). Eğitim bilimine giriş̧. Ankara: Arkadaş.

Ersoy, A. F., ve Kaya, E. (2009). Sosyal bilgiler dersi öğretim programının (2004) uygulama sürecine ilişkin öğrenci görüşleri. Kastamonu Eğitim Dergisi, 17 (1), 71-86.

Ersoy, F. G. (2009). Yeni ilköğretim sosyal bilgiler programının uygulanmast ile ilgili değerlendirmeler (Konya ili örneği) (Yayınlanmamış yüksek lisans tezi). Selçuk Üniversitesi Sosyal Bilimleri Enstitüsü, Konya.

Evin, İ. ve Kafadar, O. (2004). İlköğretim sosyal bilgiler programının ve ders kitaplarının ulusal ve evrensel değerler yönünden içerik çözümlemesi. Türk Eğitim Bilimleri Dergisi, 2(3), 293-304.

Evans, R. W. (2011). The tragedy of American school reform: How curriculum politics and entrenched dilemmas have diverted us from democracy. Palgra ve Macmillan.

Gömleksiz, M. N., ve Bulut, İ. (2006). Yeni sosyal bilgiler dersi öğretim programının uygulamadaki etkililiğinin değerlendirilmesi. Kuram ve Uygulamada Eğitim Yönetimi Dergisi, 47, 393-421.

Harland, T., \& Pickering, N. (2011). Values in higher education teaching. New York: Routledge.

Kabapınar, Y., ve Ataman, M. (2010). İlköğretim sosyal bilgiler (4-5. sınıf) programlarındaki ölçme ve değerlendirme yöntemlerine ilişkin öğretmen görüşleri. İlköğretim Online, 9(2), 776-791.

Kafadar, T., Öztürk, C., ve Katılmış, A. (2018). Farklı ülkelerin sosyal bilgiler öğretim programlarının değerler eğitimi boyutunda karşılaştırılması. Ahi Evran Üniversitesi Kırşsehir Eğitim Fakültesi Dergisi, 19(1), $154-177$. 
Keskin, Y. (2008). Türkiye'de sosyal bilgiler öğretim programlarında değerler ĕgitimi: Tarihsel gelişim, 1998 ve 2004 programlarının etkililiğinin araştırılması (Yayınlanmamış Doktora Tezi). Marmara Üniversitesi, Eğitim Bilimleri Enstitüsü, İstanbul.

Koçoğlu, E., ve Aydın, M. (2017). Alan uzmanlarına göre 2017 sosyal bilgiler programının 2005 programı çerçevesinde analizi. International Journal of Social Science Research, 6(1), 61-74.

MEB (2005). Sosyal bilgiler ögretim programı. https://ttkb.meb.gov.tr/www/ogretim-programlari/icerik/72 adresinden 12/06/2017 tarihinde erişilmiştir.

MEB (2018). Sosyal bilgiler ögrretim programı. http://mufredat.meb.gov.tr/ProgramDetay.aspx?PID=354 adresinden 12/02/2018 tarihinde erişilmiştir.

Miles, M. B., \& Huberman, A. M. (1994). Qualitative data analysis: An expanded sourcebook. Sage Publications.

Mindes, G. (2014). Social studies for young children: Preschool and primary curriculum anchor. (2. edition) Maryland: Rowman \& Littlefield education.

Ministére De Léducation Nationale (2015). Programme d'enseignement moral et civique. http://www.education.gouv.fr/pid25535/bulletin_officiel.html?cid_bo=90158 adresinden 12/06/2017 tarihinde erişilmiştir.

New York State Education Deparment (2016). Social studies core curriculum. http://www.p12.nysed.gov/ciai/socst/frameworkhome.html adresinden 12/06/2017 tarihinde erişilmiştir.

NCSS (2010). National curriculum standards for social studies: A framework for teaching learning and assessment. https://www.socialstudies.org/standards/introduction adresinden 09/07/2018 tarihinde erişilmiştir.

Oğuz Haçat, S., ve Demir, F. B. (2018). Sosyal bilim disiplinlerine göre 2005 ve 2018 sosyal bilgiler dersi öğretim programındaki kazanımların değerlendirilmesi. Uluslararası Sosyal Bilgilerde Yeni Yaklaşımlar Dergisi (IJONASS), 2(2), 27-56.

Öztürk, C. (2009). Sosyal bilgiler: Toplumsal yaşama disiplinlerarası bir bakış. C. Öztürk (Edt.). Sosyal bilgiler ögretimi demokratik vatandaşlık ĕgitimi (s. 1-31). Ankara: Pegem Akademi.

Öztürk, C., ve Kafadar, T. (2019). Fransız ve Türk okulu ortaokul öğrencilerinin değer algılarının karş1laştırılması. Eğitim ve Bilim, 44 (198), 273-290. DOI: 10.15390/EB.2019.7837.

Patton, M. Q. (2014). Nitel araştırma ve değerlendirme yöntemleri. (Çev. M. Bütün ve S. B. Demir). Ankara: Pegem A Akademi.

P21. (2016). Partnership for 21st century learning. http://www.p21.org/our-work/p21-framework adresinden 15/03/2018 tarihinde erişilmiştir.

Schwartz, S.H., Cieciuch, J., Vecchione, M., Davidov, E., Fischer, R., Beierlein, C., Ramos, A., Verkasalo, M., Lönnqvist, J.E., Demirutku, K., Dirilen-Gümüş, Ö., Konty, M. (2012). Refining the theory of basic individual values. Journal of personality and social psychology, 103, 663-688. https://www.researchgate.net/profile/Shalom_Schwartz adresinden 12/03/2018 tarihinde erişilmiştir.

Turner, T. N., Russell III, W. B. \& Waters, S. (2013). Essentials of elementary social studies. (4.edition). New York: Routledge.

TYC. (2015). Türkiye Yeterlilikler Çerçevesi. Ankara: Mesleki Yeterlilik Kurumu.

Yalar, T. (2010). İlköğretim sosyal bilgiler programında değerler ĕgitiminin mevcut durumunun belirlenmesi ve ögretmenlere yönelik bir program modülü geliştirme (Yayınlanmamış Doktora Tezi). Mersin Üniversitesi Sosyal Bilimler Enstitüsü, Mersin.

Yapıc1, M., ve Demirdelen, C. (2007). İlköğretim 4. sınıf sosyal bilgiler öğretim programına ilişkin öğretmen görüşleri. Illköğretim Online, 6(2), 204-212.

Yıldırım, A. ve Şimşek, H. (2011). Sosyal bilimlerde nitel araştırma yöntemleri. Ankara: Seçkin.

Zecha, G. (2007). Opening the road to values education. In D. N. Aspin \& J. D. Chapman (Eds.) Values education and lifelong learning: Principles policies, programmes (pp. 48-61). Springer. 